\title{
CONGRESSIONAL REAPPORTIONMENT AND NATIONAL POLITICAL POWER
}

\author{
David G. Farrelly* and IVAN Hinderaker $\dagger$
}

Since World War II there has been much speculation on the economic, social and political impact of population growth and redistribution in the United States. In 1947 the Bureau of the Census published its first estimates of $195^{\circ}$ population, and it projected trends for the decade of the 1940's. These data and the facts now uncovered by the 1950 census reveal a wealth of evidence on economic and social changes that have taken place during the last decade. Observers are sure that the political impact of population changes is equally significant. But here the lines of development are not as clear, nor as easy to trace, as in the socio-economic field.

Our system of government in the United States is not designed to be immediately and completely responsive to population shifts within the country. Once every ro years heads are counted; only then do we pause to gear our political institutions to population changes. At the national level this is done primarily by reapportioning representation so as to approximate the populations of each of our 48 states.

.The political touchstone of the r950 census returns is congressional reapportionment. Indeed, at only two points-in Congress and in the electoral college-are there any outward political manifestations of population change. The I95I reapportionment of congressional seats increased the voting strength of $\eta$ state delegations in the United States House of Representatives and decreased the size of 9. Since a state's representation in the electoral college is based on the sum total of its membership in the lower house of Congress plus its 2 United States senators, there has been a resultant and parallel redistribution of presidential-electoral votes. These two changes may be said to represent constitutional readjustment to the r950 census.

Certain relatively obvious political effects stem from reapportionment. The basic change in the electoral college will be reflected in state voting power at the national nominating conventions held by the Republican and Democratic parties in 1952, 1956, and 1960. Individual candidacies for presidential and vice-presidential nomination may well be affected. And the ability of some states to gain more high political appointments for their citizens will be enhanced or retarded.

Some of these consequences may be subjected to measurement, but others may not. The number of electoral votes is not the sole determinant of voting power at

* B.S. 1937, Springfield College; A.M. 1940, University of Pittsburgh; Ph.D. 1949, Princeton University. Assistant Professor of Political Science, University of California at Los Angeles, since 1948. Co-cditor, The Politics of California (r95I). Contributor to legal and political science periodicals.

+A.B. I938, St. Olaf College; A.M. 1942, Ph.D. 1949, University of Minnesota. Assistant Professor of Political Science, University of California at Los Angeles, since 1948. Co-cditor, Tite Pourtics of California (I95I). Contributor to political science periodicals. 
a national convention, nor does it alone furnish much of a guide to an appraisal of a state's influence. The chances of a "favorite son" capturing the presidential nomination may be advanced by an influx of population into his state, but a full assessment of his possibjitities depends upon many other factors. While pivotal states in presidential politics have received a large share of the major fruits of officeCabinet appointments, Supreme Court justiceships-pivot status is dependent upon more than population statistics.

In the House of Representatives, reapportionment will also produce certain consequences other than the decrease or increase in the size of 16 state delegations. The rank of a delegation should not be measured on the basis of voting strength alone. Does California, with its present 23 seats, rate below Illinois which has 26 representatives? Nominally it does (in actuality it probably does, too), but there are other criteria. The operation of the seniority rule in the legislative process is an important consideration. Can a delegation work as a unit on matters of fundamental interest to its state? What is the partisan composition of the delegation? What relationship exists between the members and the White House? These suggest the complications which arise when one attempts to survey the implications of reapportionment on political power in Congress.

Even if all the factors contributing to national political power were measurable, the changes produced by any one decennial reapportionment of congressional seats are usually slight. Such huge increases as have befallen California in I93I (9 seats) and in 195I ( 7 seats) are unusual. Ordinarily it takes the sum total of several reapportionment shifts before trends become established. The half-century point has now been passed. Therefore, this article is not concerned alone with the congressional reapportionment of $195 \mathrm{I}$, but it attempts to set this latest reapportionment into the context of population and political trends in the United States since Igoo.

\section{Populatton Growth and Trends}

At the end of the nineteenth century the population of the United States was 76 million. Fifty years later, in 1950 , it had reached $15 \mathrm{I}$ million and was still mounting rapidly. ${ }^{1}$ An increase of nearly roo per cent in this period is highly significant by itself. Prodigious procreation and immigration (20 million foreign-born) have brought the population figure to this height. More directly related to the problems of national political power, however, is the distribution of population among the states during this era of tremendous growth.

As compared with 1900 , population distribution in $195^{\circ}$ was most radically affected by mushroom growth in 8 states far removed from the geographical center of the country. ${ }^{2}$ California's fifty-year jump, from twenty-first to the second most

\footnotetext{
1 The 1951 reapportionment may already be out of step with population shifts. As of December I,

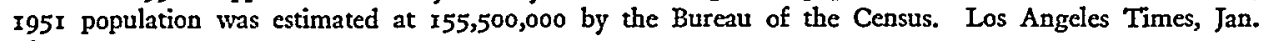
I8, 1952 .

' See Map I. Although the map is based on changes in congressional apportionment, it serves to illustrate population redistribution.
} 
populous state, has been the most spectacular development. Except for one decadethe I930's-California's advance has been taken with the same giant strides. The other 7 states which gained significantly in relative population rank are: Michigan, Texas, Washington, Oregon, Florida, New Jersey, and North Carolina. All of these states lie on the outside edge of the United States; except for Michigan they are littoral states.

On the other hand, a pattern of a different sort has been established by the states that have failed to grow proportionately with the national increase. In sharp contrast to the 8 fringe states, that have had the largest relative gain in population, are 8 core states with the most significant record of failure to expand with the national average growth. These 8 , losing most in relative population position, constitute a solid bloc of geographically center states. They are: Nebraska, Kansas, Oklahoma, Iowa, Missouri, Illinois, Indiana, and Kentucky. The territory embraced by these states is compact. Missouri is the linchpin as 6 of these states are contiguous to its borders.

Attention should be called to two minor patterns that emerge from a consideration of still other states that have lost rank. The 6 states lying southeast from Missouri fall into one cluster of losers. In another group are Pennsylvania, New York, and Massachusetts. Although these last 3 states have maintained their high rank as well-populated states, they have failed to maintain their relative position. The case of New York is a good example. Although it actually doubled its population from I900 to I950, such an increase merely conformed to the normal growth pattern of the country as a whole. The addition of over a million New Yorkers between 1940 and 1950 was not sufficient to classify the Empire State as a gainer. It is now apparent that it is not holding its own. New York dropped enough in relative population to lose 2 House seats in the reapportionment of $195 \mathrm{I}$.

All of the 48 states have increased their population during this century, although from time to time a few states have had temporary setbacks in terms of actual decade loss. $^{3}$ Whereas 8 states grew disproportionately greater, exactly half of the states failed to keep steady pace with the overall population increase.

Marked shifts of population within the United States during the first half of the twentieth century should occasion no surprise. Population mobility has advanced tremendously since rgoo. The automobile has progressed from a gleam in an inventor's eye to a car in Everyman's garage. The airplane and its successive developments have produced a means of extremely rapid transit. Atomic energy holds new vistas before our eyes at the half-century point. Other factors have tended to expedite and encourage movement; there have been parallel developments in other types of transportation and in methods of communication. Nor should one neglect to consider the stepped-up impact of the industrial revolution and the uprooting effects of two world wars.

${ }^{3}$ For example, North Dakota, Mississippi, Arkansas, and Oklahoma in the decade, 1940-1950. 
Highly significant is the intensity of movement during this last decade. Final census data are not yet available, but by 1947 there was much evidence that there had been a great shifting around since I940. Seventy million people were living in homes that they had not lived in on April I, I940. Thirteen million persons changed counties within their state of residence. Five million crossed borders into contiguous neighboring states; nearly seven and a half million moved to non-contiguous states. ${ }^{4}$

America has moved to the city during this century. Since I9ro, the number of persons in urban territory has increased 99.8 per cent while the rural population decreased 13.4 per cent. ${ }^{5}$ At the end of the nineteenth century the United States was 39.7 per cent urban; by 1920 , for the first time, urban dwellers were in the majority ( 51.2 per cent); and in I950 the nation was 64 per cent urban.

Movement away from the farm and the relative growth-failure of farm-bloc states is a causal explanation (but a negative one) for the centrifugal build-up of population in the United States. There are other and positive reasons for population growth in the 8 states on the perimeter of the country. Two states-California and Florida-have strong climatic advantages that have encouraged population increase. In addition, California has had vast developments in aircraft, steel, oil, shipyard, and entertainment industries; and its agriculture has expanded. The automotive industry and related businesses have aided Michigan's development; its mineral production has increased, too. Oregon and Washington have developed their water power and other abundant resources; booming aluminum and atomic industries have found a home in the Pacific Northwest. In the west south-central area, Texas has one of the nation's most rapidly expanding industrial plants with its natural gas, oil, and chemical developments. The states adjacent to the District of Columbia have caught the overflow of populace from the national capital. New Jersey's strategic position near the great market centers of the East has aided its development materially.

In further analysis of the centrifugal movement of people, the fluidity of the mass migration has had a general westward course. The geographical center of the United States' population was 6 miles southeast of Columbus, Indiana in rgoo. For the next 40 years its westward trend across Indiana proceeded at the rate of some $2 \mathrm{I}$ miles per decade. But during the r $944^{\prime}$ 's the movement was accelerated 42 miles in a westerly direction to cross the Indiana border into Richland County, Illinois.

The Pacific Coast and the southwestern states in particular have been the beneficiaries of regional developments: big industry, irrigation of new farm land, electrical power, and reclamation projects. No other area has experienced such broad-scale development in such a comparatively short space of time as 50 years. ${ }^{6}$ Utilizing census

\footnotetext{
"See Edwards, Population Changes in the United States, 265 Annats 80, 89 (1949).

${ }^{5}$ See Population Shifts Away from the Farms, United States News and World Report, Oct. 2x, I949, pp. $24,25$.

'See 37 Billions to Remake the West, id. Dec. 2, 1949, at pp. 17-20.
} 
data and Bureau of Agricultural Economics studies, it is estimated that there will be a continuation of the westerly trend. The Pacific Coast states will grow most rapidly; the industrial East and South will probably keep pace with the national average growth; midwestern states may fall below the average growth; New England will grow more slowly than the other expanding sections.?

Much speculation has followed in the wake of developments in the "new West." The editor of Western Industry, A. C. Prendergast, sees the United States on the verge of a shift of economic and financial power from the East and Middle West to the Far West and Southwest. ${ }^{8}$ Many others have taken a further step by suggesting that both economically and politically California tips the national balance westward. Does the political impact necessarily follow? If it does, to what extent?

\section{Presidential Politics}

\section{A. The Electoral College}

Under the electoral-college system of choosing the president and vice president, the machinery of election is tailored to fit the national representation accorded each state. Every state has as many electors as it has congressmen and United States senators. Therefore, decennial changes in the apportionment of representatives have a direct effect upon presidential elections.

By I9I2 the last of the 48 states had been admitted into the Union. In the presidential election of that year the total electoral vote was increased to 531, the highest it had ever been allowed to reach. And the presidential electoral vote has remained at this plateau level ever since. In I 929 the number of United States representatives was "permanantly" established at 435 by the Automatic Reapportionment Act." This statute had the effect of clamping a lid on political power. Thereafter, when population change warranted it, electoral votes would have to be redistributed. Some states would be required to yield electoral votes if their population failed to attain proportional growth; other states would gain strength in the electoral college if their population grew disproportionately large.

In Table I basic information is furnished on the electoral votes of the states during this century.

The congressional reapportionment of $195 \mathrm{I}$ has forced a redistribution of some $x_{4}$ electoral votes. Political effects of the resultant changes may be partially ascertained by an examination of the composition of the "new" electoral college. This may be done by comparing the Truman-Dewey election of 1948 on a state-by-state basis with the electoral college as it will be constituted during the decade of the r950's.

Looking back, then, upon the contest of 1948 we can readily see how that election would have been decided if the I95I reapportionment had been used at that time.

\footnotetext{
' See Where Best Markets Will Be, id. Dec. 9, x949, at pp. 44, 45.

As reported in the Christian Science Monitor, Oct. 28, I950.

${ }^{8}{ }_{46} 6$ STAT. 26 (I929), 2 U. S. C. \$2a (Supp. 1950).
} 
TABLE I. The Electoral College*

\begin{tabular}{|c|c|c|c|c|c|c|c|c|c|c|c|}
\hline \multirow[t]{2}{*}{ State } & \multirow{2}{*}{\multicolumn{2}{|c|}{$1901 \stackrel{\text { RANK }}{1951}$}} & \multirow[t]{2}{*}{1904} & \multirow[t]{2}{*}{$\underset{1912}{\mathrm{EL}}$} & \multirow[t]{2}{*}{$\begin{array}{l}\text { TORAI } \\
1932\end{array}$} & \multirow[t]{2}{*}{$\begin{array}{l}\text { OTE } \\
1944\end{array}$} & \multirow[t]{2}{*}{1952} & \multicolumn{2}{|c|}{$\begin{array}{c}\text { Crange } \\
\text { 1941-1952 }\end{array}$} & \multicolumn{2}{|c|}{$\begin{array}{c}\text { CHANGE } \\
\text { 1912-1952 }\end{array}$} \\
\hline & & & & & & & & Gain & Loss & Gain & Loss \\
\hline & 21 & 1 & 39 & 45 & 47 & 47 & 45 & & 2 & & \\
\hline $\begin{array}{l}\text { CALIF.. } \\
\text { Penna... }\end{array}$ & $\begin{array}{r}21 \\
2\end{array}$ & 2 & 10 & 13 & 22 & 25 & 32 & 7 & & 19 & $\because$ \\
\hline Ill... & 3 & 4 & 27 & $\begin{array}{l}38 \\
29\end{array}$ & $\begin{array}{l}50 \\
29\end{array}$ & $\begin{array}{l}30 \\
28\end{array}$ & $\begin{array}{l}32 \\
27\end{array}$ & $\cdots$ & 3 & .. & 6 \\
\hline Ohio... & 4 & 5 & 23 & 24 & 26 & 25 & 25 & $\because$ & 1 & $\dddot{i}$ & 2 \\
\hline TEXAS & 6 & 6 & 18 & 20 & 23 & 23 & 24 & $\because$ & $\ddot{1}$ & $\frac{1}{4}$ & .. \\
\hline MICH....... & 9 & 7 & 14 & 1 & 19 & 19 & 20 & $\because$ & 1 & 5 & $\ddot{0}$ \\
\hline N. JERSEY.... & 16 & 8 & 12 & 14 & 16 & 16 & 16 & . & .. & 2 & \\
\hline Mass........... & 7 & 9 & 16 & 18 & 17 & 16 & 16 & $\because$. & $\ddot{0}$ & & $\ddot{2}$ \\
\hline N. CAROLINA. & 15 & 10 & 12 & 12 & 13 & 14 & 14 & $\because$ & $\cdots$ & $\ddot{2}$ & 2 \\
\hline Mo............. & 5 & 11 & 18 & 18 & 15 & 15 & 13 & $\because$ & $\ddot{2}$ & 2 & $\ddot{5}$ \\
\hline $\operatorname{Ind} . .$. & 8 & 12 & 15 & 15 & 14 & 13 & 13 & .. & .. & .. & 2 \\
\hline Ga............. & 11 & 13 & 13 & 14 & 12 & 12 & 12 & .. & $\because$ & $\therefore$ & 2 \\
\hline Wisc........... & 13 & 14 & 13 & 13 & 12 & 12 & 12 & $\cdots$ & $\ddot{.}$ & 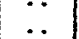 & 1 \\
\hline Va........ & 17 & 15 & 12 & 12 & 11 & 11 & 12 & $\ddot{i}$ & . & $\ddot{0}$ & 1 \\
\hline Tenn... & 14 & 16 & 11 & 12 & 11 & 12 & 11 & $\ldots$ & $\ddot{i}$ & $\because$ & $\ddot{i}$ \\
\hline Ala.... & 18 & 17 & 11 & 12 & 11 & 11 & 11 & .. & .. & .. & 1 \\
\hline Minn... & 19 & 18 & 11 & 12 & 11 & 11 & 11 & $\cdots$ & $\cdots$ & $\because$ & 1 \\
\hline$k y \ldots . .$. & 12 & 19 & 13 & 13 & 11 & 11 & 10 & .. & $\ddot{i}$ & $\because$ & 3 \\
\hline & 23 & 20 & 9 & 10 & 10 & 10 & 10 & .. & & $\because$ & $\ldots$ \\
\hline FLA... & 33 & 21 & 5 & 6 & 7 & 8 & 10 & $\ddot{2}$ & .. & $\ddot{4}$ & $\cdots$ \\
\hline Iowa.... & 10 & 22 & 13 & 13 & 11 & 10 & 10 & & .. & & 3 \\
\hline WASH.. & 34 & 23 & 5 & 7 & 8 & 8 & 9 & 1 & 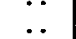 & $\ddot{2}$ & .. \\
\hline Md...... & 26 & 24 & 8 & 8 & 8 & 8 & 9 & $\overrightarrow{1}$ & .. & 1 & $\ddot{. .}$ \\
\hline Olila... & 30 & 25 & & 10 & 11 & 10 & 8 & & $\ddot{2}$ &. & $\ddot{2}$ \\
\hline Miss... & 20 & 26 & 10 & 10 & 9 & 9 & 8 & .. & 1 & .. & $\overline{2}$ \\
\hline S. C.... & 24 & 27 & 9 & 9 & 8 & 8 & 8 & .. & .. & $\because$ & 1 \\
\hline Conn... & 29 & 28 & 7 & 7 & 8 & 8 & 8 & $\therefore$ & $\because$ & $\ddot{i}$ & $\ldots$ \\
\hline W. Va.. & 28 & 29 & 7 & 8 & 8 & 8 & 8 & $\therefore$ & $\therefore$ & & $\ddot{.}$ \\
\hline Ark..... & 25 & 30 & $\dot{9}$ & 9 & 9 & 9 & 8 & $\ddot{. .}$ & $\ddot{i}$ & $\because$ & $\ddot{i}$ \\
\hline Kan.... & 22 & 31 & 10 & 10 & 9 & 8 & 8 & .. & .. & $\therefore$ & 2 \\
\hline Ore... & 36 & 32 & 4 & 5 & 5 & 6 & 6 & .. & .. & $i$ & 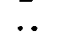 \\
\hline Nebr... & 27 & 33 & 8 & 8 & 7 & 6 & 6 & $\because$. & $\ddot{. .}$ & $\ldots$ & $\ddot{2}$ \\
\hline Colo.... & 32 & 34 & 5 & 6 & 6 & 6 & 6 & $\because$ & $\because$ & $\because$ & \\
\hline $\operatorname{Me} . . .$. & 31 & 35 & 6 & 6 & 5 & 5 & 5 & .. & .. & .. & 1 \\
\hline R. I.... & 35 & 36 & 4 & 5 & 4 & 4 & 4 & .. & .. & .. & $\overline{1}$ \\
\hline & 46 & 37 & & 3 & $\overline{3}$ & 4 & 4 & $\therefore$ & .. & $\ddot{i}$ & \\
\hline Utah.. & 41 & 38 & 3 & 4 & 4 & 4 & 4 & $\ddot{.}$ & $\ddot{. .}$ & & .. \\
\hline N.M. M. & 43 & 39 & & 3 & 3 & 4 & 4 & .. & .. & 1 & . \\
\hline S. D.... & 38 & 40 & 4 & 5 & 4 & 4 & 4 & .. & .. & .. & 1 \\
\hline N. D...... & 40 & 41 & 4 & 5 & 4 & 4 & 4 & $\ldots$ & .. & . & $\overline{1}$ \\
\hline Mont....... & 42 & 42 & 3 & 4 & 4 & 4 & 4 & .. & .. & .. & .. \\
\hline Ida........ & 45 & 43 & 3 & 4 & 4 & 4 & 4 & .. & . & .. & .. \\
\hline $\begin{array}{l}\text { N. H. } \\
\text { vt. }, \ldots, \ldots, \cdots\end{array}$ & $\begin{array}{l}37 \\
39\end{array}$ & $\begin{array}{l}44 \\
45\end{array}$ & $\frac{4}{4}$ & $\begin{array}{l}4 \\
4\end{array}$ & $\begin{array}{l}4 \\
3\end{array}$ & 4 & 4 & . & $\because$ & .: & $\ddot{i}$ \\
\hline Del.................... & 44 & 46 & $\frac{ \pm}{3}$ & 3 & $\stackrel{5}{3}$ & $\begin{array}{l}3 \\
3\end{array}$ & $\stackrel{5}{3}$ & $\because$. & $\because$. & .. & .. \\
\hline Wyo.... & 47 & 47 & 3 & 3 & 3 & 3 & 3 & .. & $\ddot{.}$ & .. & $\because$. \\
\hline Nev........ & 48 & 48 & 3 & 3 & 3 & 3 & 3 & .. & .. & .. & .. \\
\hline
\end{tabular}

* Btates gaining two or more electoral votes are in caps.

States losing two or more electoral votes are in italies.

Mr. Truman would still have defeated Mr. Dewey, and by a slightly higher margin. The President would have received 307 electoral votes instead of 303. Dewey would have lost 3 votes; the Dixiecrat nominee, J. Strom Thurmond, I (from Mississippi). If this test is valid, in all probability the next three presidential elections will not be decisively affected by the mathematical redistribution of electoral votes as occasioned by the reapportionment of 195 r. 
Shifts in population result in decennial reapportionment that is discernible in terms of the distribution of electoral votes, but there are other consequences that are less tangible in nature. Map I, which shows losses and gains of electoral votes since Igr2, is useful to the discussion which follows on partisanship, urbanization, and sectionalism.

If one considers the party affiliation of the states that have gained or lost electoral votes, several conclusions emerge. First, the traditionally Democratic Solid South has lost 2 electoral votes as a result of the recent reapportionment. ${ }^{10}$ Whereas Florida, Texas, and Virginia gained 4 votes among them, there was a loss of 6 votes from Mississippi, Tennessee, Arkansas, Kentucky, and Oklahoma. Overlooking the continued threat of disaffection from Democratic ranks by the Dixiecrat movement, there is a net loss of 2 electoral votes in the Solid South.

Second, it appears that 2 electoral votes have been lost to the Republican party. After the period of President Franklin D. Roosevelt, it may be questioned if there are many safe Republican states. But of those states that have recently lost electoral votes, Pennsylvania has been most consistently in the G.O.P. column, and Michigan leans Republican, too. Pennsylvania's loss of 3 votes overbalances Michigan's gain of $I$ and results in a net decline of 2 electoral votes for the Republican party.

Third, the loss of 2 Democratic and 2 Republican votes has been picked up by states in the so-called doubtful group.11 The doubtful states are those in which the two-party rivalry is so close that neither major party can rely upon winning their electoral votes. Three states in this classification (New York, Illinois, and Missouri) lost a total of 5 votes. This was more than offset by a total of 9 electoral votes gained by California, Washington, and Maryland.

Thus there appears to be a slight trend when the $195 \mathrm{I}$ electoral-vote changes are related to partisanship voting behavior. There has been a loss of 2 electoral votes each by the Democratic and Republican parties; doubtful states acquired these 4 votes.

Except for the slight waning of southern political power in the electoral college, this recent trend conforms rather well to a pattern that has been manifest during the twentieth century. The rg states that may be said to lean toward the Republican party have lost some $\mathrm{x} 2$ electoral votes since $1912 .{ }^{12}$ On the other hand, the combina-

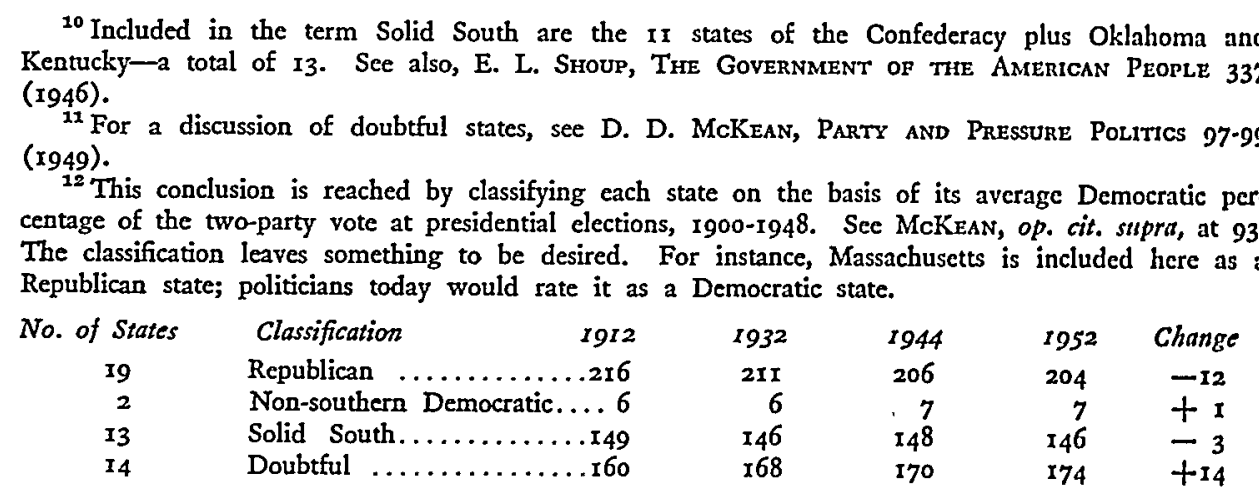


tion of doubtful states has increased its strength by 14 -from 160 to I74 electoral votes. It is repeating a truism to mention that the doubtful states possess the balance of power in presidential elections.

A generation ago, Professor Arthur N. Holcombe noted that increasing urbanization had reduced the influence of the farmer in presidential elections. ${ }^{13}$ Holcombe's generalization suggests another survey of the electoral college; this analysis relates to the urban-rural composition of the vote.

In I932, by Census Bureau definition, there were 2I urban states whose sum total of electoral college votes was 310-a clear majority. Theorizing in the abstract, one of the major parties could capture the presidency without support from voters in rural states. Since I932 urbanization has continued apace. More people live in cities; there are far fewer farms and farmers. How has this trend affected the electoral college?

The net result of population shifts and overall growth has been to increase the electoral strength of the urban states while reducing the strength of rural states. As an immediate result of reapportionment in I95I, 4 electoral votes were added to the combined total of $3^{\text {Io }}$ possessed by the $2 \mathrm{r}$ urban states, making an electoral majority of $3^{\mathrm{I}} 4$ votes. ${ }^{14}$ Considering the states that lost electoral votes, 6 votes were lost by 5 rural states (Arkansas, Kentucky, Mississippi, Oklahoma, and Tennessee); 8 votes were dropped by 4 urban states (Illinois, Missouri, New York, and Pennsylvania). In the redistribution, I rural vote was picked up by a rural state (Virginia) whereas the remaining 5 rural votes plus the 8 urban votes were all acquired by 6 urban states (California, Florida, Maryland, Michigan, Washington, and Texas).

But more than this, 4 additional states (Minnesota, Louisiana, Texas, and Nevada) are now entitled to classification as urban. ${ }^{15}$ Their electoral votes thus swell the urban states' total to $362-$ a new high. Proportionately, there are 23 rural states today with a total electoral vote of 169 . Considering city vis-á-vis country interests, urban states in 1952 wield the greatest influence in the electoral college that they have ever had.

${ }^{13}$ A. N. Holcombe, The New Party Polttics $3 \mathrm{~T}-34$ (I933).

14 The one electoral vote acquired by Texas is not included.

15 The authors have deliberately retained the old Census Bureau definition of "urban" in order to make a valid comparative measurement of the urbanization trend. The new meaning of "urban" is a change in definition that "involves the substitution of specially delimited urban fringe areas and unincorporated places for places classified as urban under special rules." BUREAU of tHe CENSUs, I950 CENSUs of Population, Preliminary Counts, Population of the United States, Urban and Rurat, by States, Aprir I, I950 (Series PC-3, No. IO) I-3 (U. S. Dep'T of Commerce, Feb. I6, I95I).

Actually, Minnesota, Louisiana, Texas, and Nevada are now urban states under both old and new definitions of "urban." But 5 other states-Maine, Kansas, Oklahoma, Arizona, and New Mexico-now are classified as urban under the r950 definition. However, by the old definition they are still rural, hence their exclusion. Of course, if these 5 states are added to the list of urban states, it means that there are 29 urban states with a combined total of 391 electoral votes as against I9 rural states with 140 votes.

Apropos the new definition of "urban," and having visited the new urban states of Arizona and New Mexico, the authors are reminded of Mark Twain's classification of prevaricators as "liars, damn liars, and statisticians." 
Any consideration of sectionalism should not be divorced from the urban-rural factor, nor partisan politics. Yet these latter elements of political power have already received attention by themselves. Basic area divisions have also played an important role in presidential elections. Conflicts between North and South, and between East and West have focused attention on the geographical basis of national politics. Without giving precise definition to political sections, it is our purpose here merely to suggest the impact of the $195 \mathrm{x}$ reapportionment on sectional representation in the electoral college.

Using Bureau of the Census breakdowns of areas, it is apparent that two sections of the country have gained political power-namely, the Pacific Coast and the South Atlantic regions. ${ }^{16}$ Due to California's increase of $\eta$ votes and Washington's $r$, the Pacific Coast is the largest decennial gainer. The South Atlantic area increased its political power by 4 votes (Maryland r, Virginia I, Florida 2). Both of these gains have been made at the expense of the Middle Atlantic area (losing 5 votes), the West North Central ( 2 votes), the East South Central (3 votes), and the West South Central (I vote).

The long-range changes have been more important, however, as a glance at Map I will show. The II western states, all lying west of $102^{\circ}$ longitude, have achieved the one noteworthy gain in electoral votes during this century. Of course California has been almost singly responsible for this westward flow of electoral votes. But it has received assistance from Washington, Oregon, Arizona, and New Mexico-each situated on the periphery of the United States. And the other 6 western states have all kept abreast of the national growth rate.

Reckoned only from I9I2, when the size of the electoral college was fixed at the maximum of 531, the West has picked up 24 votes. As a whole the West today has 79 votes; in 1912 it had 55 . Percentagewise, the western states now hold I5 per cent of the electoral votes as against ro per cent in rgr2 and 8 per cent in rgor.

By and large, this western gain has been made at the expense of the American heartland. Much political power has been squeezed out of that expansive area stretching from the Appalachians to the foothills of the Rocky Mountains. In other words, as seen on Map I, the Mississippi Valley-Great Plains region has lost considerable strength.

Lest the half-century shift be misleading, it is important to remember that the situs of electoral strength is still largely in the eastern part of the United States. Map II shows those states that today possess to or more electoral votes. ${ }^{17}$

At the start of this century the most populous and politically powerful states were those whose borders touched the Great Lakes: New York, Pennsylvania, Ohio, and

${ }^{10}$ The Bureau of the Census divisions are New England, Middle Atlantic, East North Central, Wcst North Central, South Atlantic, East South Central, West South Central, Mountain and Pacific. E.g., Statistical Abstract of the United States, 1948 .

${ }^{17}$ On Map II, Louisiana and Florida are the only additions since I90I to the list of states that have Io or more electoral votes. Kansas and Mississippi were once, but are no longer, in this class. 
Illinois. The trend since Igoo shows that California, Texas, and Michigan have some of the attributes necessary to join them. For the first time a state from the far west (California) and one from the southwest (Texas) have moved up into the select circle of states that possess 20 or more votes in the electoral college. And in point of fact, these two states are the only ones in the entire western half of the country that appear on Map II.

\section{B. The National Convention}

Another aspect of presidential politics-the national nominating process-will be affected by the $195 \mathrm{I}$ reapportionment. Congressional representation is the principal criterion used to determine the size of state delegations to the Democratic and Republican conventions. However, both parties employ a bonus system to reward partisan voting behavior, and this device influences the apportionment of convention delegates. Thus a state may have a significant gain or loss if it were measured solely by the new size of its congressional representation, but the bonus system may undermine the effect.

Basically, the Democratic formula for allocating voting strength to the states at the 1952 Chicago convention is the same as that used in 1948 . Representation is determined as follows: 2 for each congressional district or congressman-at-large; 2 for each senator; and 4 for each state that went Democratic in the 9948 presidential election. In this year's convention, however, an important exception has been made by the party's national committee. No votes have been taken from those states that lost congressional seats by virtue of the $195^{\circ}$ census. ${ }^{18}$ Thus 6 of the 9 states adversely affected by reapportionment have the same voting strength in 1952 as they had in I948. These states are: Arkansas, Illinois, Kentucky, Missouri, Oklahoma, and Tennessee. On the other hand, Mississippi, New York, and Pennsylvania do lose delegate strength despite the concession by the Democratic National Committee. Each of these latter states is penalized to the extent of 4 votes in the 1952 convention because it failed to give its electoral vote to Mr. Truman in I948. Mississippi supported Thurmond four years ago; New York and Pennsylvania were won by Dewey.

Of the 7 states gaining by congressional reapportionment, California receives the only substantial benefit-I4 additional full-voting delegates. Florida adds 4 delegates to its I948 allotment. Texas, Virginia, and Washington each gains 2 votes. Maryland and Michigan should have increased their representation in the 1952 convention, but instead each actually lost some voting strength. Whereas they both gained 2 votes for having an additional congressman, they lost 4 votes apiece because Truman failed to carry those states in the I948 election (net loss: 2 votes each).

Members of the Republican national convention are chosen on a somewhat different basis than that employed by the Democrats. For delegates to the 1952 meeting,

\footnotetext{
${ }^{18}$ Democratic National Committee, 5 Capital Comment 2 (June 2, I95I); Hugh A. Bone, AMrerican Polmtics and the Party System 537 (1949).
} 
state representation will be accredited as follows: 4 for each state; I for each congressional district; 2 for each congressman-at-large; $I$ for each congressional district in which ro,000 or more popular votes were cast for Republicans in the $194^{8}$ presidential election, or in the I950 congressional election; 6 for each state that voted Republican in the $194^{8}$ presidential contest, or has since elected a Republican senator or governor. ${ }^{19}$ According to this formula, and unlike the Democratic pattern, every one of the 16 states affected by the I95I reapportionment either gains or loses delegates.

In the Republican convention California is again the chief beneficiary. It will have I7 more delegates at the Chicago convention that it had in 1948 at Philadelphia. Of its 70 delegates, 64 represent the 30 congressmen and 2 senators, and 6 are added because Richard Nixon replaced a Democratic senator in 1950. Maryland makes the next most important gain-8. Michigan, Texas, and Washington each boost their 1948 convention strength by 5 delegates. Florida and Virginia increase theirs by 2. It should be noted that 4 of these states received the 6-delegate bonus: California, Maryland, Michigan, and Washington.

With one exception all of the states losing congressional representation by the census suffer declines in delegate strength at the 1952 Republican nominating convention. Illinois has actually managed to increase the size of its delegation. Its loss of I House seat is offset by the bonus it receives for defeating the former Senate majority leader, Scott Lucas, in r950. It thus gains 4 delegates over 1948.

The other loser states drop from I to 7 convention votes, but in the case of 2 losers (Pennsylvania and New York) the bonus system mitigates the effects of fewer congressmen. Although it lost 3 congressmen, Pennsylvania defeated the Democratic party whip, Francis Myers, in 1950, and therefore shows a net loss of only 3 delegates. New York lost 2 congressmen, yet its Republican electoral vote in 1948 results in an actual loss of only I convention delegate.

A final item of comment stems from a comparison of the Democratic and Republican conventions of 1952 as they are affected by the recent reapportionment. The total increase in votes at the 1952 Democratic convention for the 7 states that have gained House seats is 24 (with I4 of these accruing to California); the 9 states losing congressional seats show a net decline of 12 convention votes. In the 1952 Republican national convention the 7 states that have gained seats in the House achieved a total increase of 44 delegates (including $\mathrm{I} 7$ from California); the 9 states losing congressional representation have a combined loss of 25 convention delegates. It is apparent, therefore, that both Democratic and Republican systems of choosing delegates to the national conventions yield approximately the same result in terms of the proportionate relationship between the 7 states increasing their congressional representation and those 9 states losing seats in Congress. This result occurs despite the fact that the Republican party has taken immediate recognition of the census

\footnotetext{
${ }^{19}$ Republican National Commitree, Call for the Republican National Convention for 1952. The only change from the 1948 formula relates to the basis of awarding the 6 bonus votes.
} 
changes whereas the Democratic party has failed to penalize directly those states that lost seats in the House of Representatives. And in the case of each political party, its bonus system operates in certain states to counterbalance the positive or negative effects of congressional reapportionment.

\section{Pivot States}

One of the least measurable effects of the I95I reapportionment applies only to the large states which possess many electoral votes. Taking into account the halfcentury trends, it is apparent that a new pivot state has entered the political arena. As of I95I California has wheeled solidly into position behind the number one pivot state-New York.

The electoral votes of pivot states are a decisive factor in presidential elections. To acquire pivotal status, a state must have one of the largest blocs of votes in the electoral college. Its political allegiance must be doubtful so that a presidential contest may go either to a Republican or a Democrat. A strategic geographical location may enhance its position.

New York has long been the most important pivot state. The I95I reapportionment has advanced California to a point where it is now New York's western counterpart. Illinois and Ohio in the midwest retain their rank as pivot states.

All 4 of these states rate high in the total number of their electoral votes. Further, each is entitled to classification as a doubtful state. In the 21 presidential elections since the Civil War, New York and Ohio supported 17 winning candidates; California and Illinois voted for $\mathrm{x} 8$ victors.

Since 1888 , California has the most impressive record of doubtfulness; with one exception it has supported the winner. When doubtful status is computed on the basis of the average percentage of the two-party vote, the smallest deviation from 50 per cent indicates the highest rating. California's average Democratic percentage of the two-party vote in this century is 49.I, making it the most politically doubtful state in the country. ${ }^{20}$

Close presidential contests have been the general rule in these pivot states. In the Truman-Dewey election of 1948 , for instance, a shift of 9,000 votes in California, I7,000 in Ohio, and 3,600 in Illinois would have brought victory to Mr. Dewey. In that election California's I8,000 plurality for Truman was not nearly as close a margin as those produced by other presidential elections. Since the Civil War 3 races were decided by less than $25^{\circ}$ popular votes; and 4 elections were won by less than 7,000 popular votes. ${ }^{21}$

By the criteria of electoral votes, doubtfulness, and close elections, California must now be classed as a pivot state. Although Pennsylvania ranks equally with California in number of electoral votes, its record of Republican partisanship has dis-

${ }^{20} \mathrm{McK}$ Ean, op. cit. supra note $\mathrm{Ir}$, at $93,98$.

${ }^{21}$ Although California could not be considered as having pivotal status in 1916, a shift of slightly over 2,000 popular votes would have given its 13 electoral votes and the presidency to Charles Evans Hughes instead of Woodrow Wilson. 
qualified it from pivot status. Michigan and Texas rank sixth and seventh, respectively, in the electoral college. But they, too, are not politically doubtful; their tradition of partisanship has offset their gain in electoral votes. Michigan's strong G.O.P. heritage has recently displayed signs of wear, although its twentieth-century record is largely Republican. Texas is much the worse off; except in 1928 it has been safely Democratic.

A pivot state is the stamping ground for presidential and vice-presidential candidates. As a general rule, a candidate with residence in a pivot state has the best opportunity for nomination. Of course there are many other factors that help to determine "availability," not the least of which is that of achieving sectional balance by the judicious choice of a vice-presidential nominee. Thirty-eight of the 48 presidential and vice-presidential candidates nominated by the two major parties have, in the I2 elections since I90I, come from the Ir states which have had 15 or more electoral votes. New York alone has furnished candidates on I4 occasions; Ohio and Indiana, 6 times each. Certainly the slight loss in power to New York and Ohio brought about by proportionately lower census returns has not seriously impaired their position as incubators for presidential candidates. Nor should the

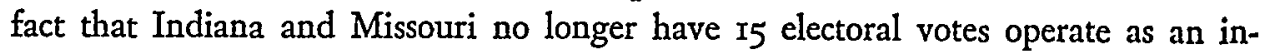
superable handicap; each state still has an advantageous geographical location.

Fifty years ago a California "favorite son" could not be considered seriously as a candidate for president or vice president. Today, the high quality of California's pivotal status places a premium before both major parties to consider the feasibility of including a Californian on the national ticket. If a party leader from California does not choose to run, or if he cannot get the nomination, he is still going to be able to exercise considerable influence on the selections that are made.

As lack of a doubtful rating may impede presidential hopefuls from Pennsylvania, Michigan, and Texas, one factor peculiar to California politics must be cited as a possible limitation on future California nominations. Party organization is extremely weak in California. Nonpartisanship is the key to statewide political success. Leaders like the late Hiram Johnson and Earl Warren may achieve great popularity within the state, but they are not easily acceptable to many of the Republican party regulars outside the state. Whether this would apply to California Democratic leaders of like stature it is difficult to say, because to date there have been none.

In addition to providing potential presidents and vice presidents, there are other fruits of pivot status. Political realists know that "party politics functions on the basis of quid pro quo."22 The building and maintenance of a successful sectional and group-interest combination is essential if a national administration is to perpetuate itself in office. This objective is accomplished in many ways, but one means of keeping a party in power is to reward the faithful for past contributions

22 W. E. Binkiey, American Polmticai Parties: Their Natural History 396 (1945). 
to successful election campaigns and to appoint rising politicos to the "in" group when they indicate that they may aid the party in the future.

In providing personnel for federal offices the party in power seeks men of ability and influence. One consequence of this is that states with large numbers of electoral votes are courted by the administration for capable personnel. Considering cabinet appointments and nominations to the Supreme Court as a rough index, the II most populous states have fulfilled this function well during the twentieth century. Slightly over two-thirds of all cabinet appointments have been from these states. Even in Supreme Court appointments, where the sectional factor is important, over one half of the justices have come from the populous states. ${ }^{23}$

California's rapid rise to the forefront of the electoral college and its achievement of pivot status, may betoken an increasing share of political fruits. ${ }^{24}$ But as nonpartisanship may tend to act as a brake on opportunities for presidential nomination, it may likewise affect other political awards. And there are still other factors in the California political scene that may make it difficult to enjoy the fruits of pivot rank. The state is 3,000 miles away from the national capital; even shrinkage of the time-space factor is no compensation for close proximity to the center of national political life. Hence, California's geographical location is a detrimental element of some consequence. California has been largely Republican in the state administrations it has elected. While this may have been advantageous prior to I932, the one-party condition of local politics has not been rewarding with a Democratic national administration in power since r933. A weak party structure makes it difficult to develop leadership that can fit into the national political organization and capitalize on the state's climb into pivotal position.

\section{iII. Congressional Power}

Fourteen of the 435 seats in the United States House of Representatives were reapportioned in I95I. This change may be compared to I94I when 9 seats were

\begin{tabular}{|c|c|c|c|}
\hline${ }^{23}$ States by rank & $\begin{array}{c}\text { Cabinet } \\
\text { Appointments }\end{array}$ & $\begin{array}{l}\text { Supreme Court } \\
\text { Appointments }\end{array}$ & Total \\
\hline New York ......... & $\ldots .28$ & 5 & 33 \\
\hline \multicolumn{2}{|c|}{ California $\ldots \ldots \ldots \ldots \ldots \ldots \ldots \ldots \ldots \ldots \ldots \ldots, 6$} & - & 6 \\
\hline \multicolumn{2}{|c|}{ 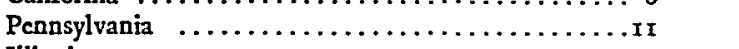 } & $\mathbf{r}$ & 12 \\
\hline \multicolumn{2}{|c|}{ 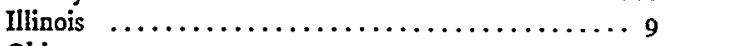 } & - & 9 \\
\hline \multicolumn{2}{|c|}{ 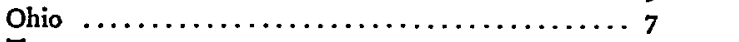 } & 3 & ro \\
\hline \multicolumn{2}{|c|}{ 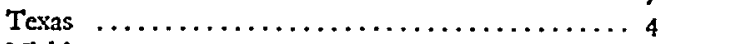 } & $\mathbf{I}$ & 5 \\
\hline \multicolumn{2}{|c|}{ Michigan $\ldots \ldots \ldots \ldots \ldots \ldots \ldots \ldots \ldots \ldots$} & I & 5 \\
\hline \multicolumn{2}{|c|}{ 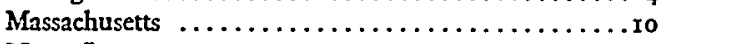 } & 4 & I4 \\
\hline \multicolumn{2}{|c|}{ New Jersey.................... } & I & 3 \\
\hline \multicolumn{2}{|c|}{ Indiana $\ldots \ldots \ldots \ldots \ldots \ldots \ldots \ldots \ldots \ldots \ldots \ldots \ldots \ldots \ldots \ldots \ldots$} & I & 4 \\
\hline \multicolumn{2}{|c|}{ Missouri $\ldots \ldots \ldots \ldots \ldots \ldots \ldots \ldots \ldots$} & - & 9 \\
\hline \multirow{2}{*}{\multicolumn{2}{|c|}{$\begin{array}{l}\text { II-state total } \ldots \ldots \ldots \ldots \ldots \ldots \ldots \ldots \ldots \ldots \ldots \ldots \ldots, \ldots 3 \\
\text { all other states. } \ldots \ldots \ldots \ldots \ldots \ldots \ldots \ldots \ldots \ldots \ldots 43\end{array}$}} & I7 & IYo \\
\hline & & I4 & 57 \\
\hline \multicolumn{2}{|c|}{ Grand total $\ldots \ldots \ldots \ldots \ldots \ldots \ldots \ldots \ldots \ldots \ldots \ldots \ldots \ldots$} & $3 \mathrm{I}$ & 167 \\
\hline
\end{tabular}

24 For a full discussion see the authors' Pivot State of the West, Frontier, May, 1951, p. 13. 
affected and 193r when 27 were readjusted. The breakdown of gains and losses for the 195 r reapportionment is as follows:

\begin{tabular}{|c|c|c|c|c|c|c|c|}
\hline \multirow[b]{2}{*}{ State } & \multicolumn{3}{|c|}{ GaINERS } & \multirow[b]{2}{*}{ State } & \multicolumn{3}{|c|}{ LOSERS } \\
\hline & $\begin{array}{c}\text { Present } \\
\text { Seats }\end{array}$ & $\begin{array}{l}\text { New } \\
\text { Seats }\end{array}$ & Change & & $\begin{array}{l}\text { Present } \\
\text { Seats }\end{array}$ & $\begin{array}{l}\text { Now } \\
\text { Seats }\end{array}$ & Change \\
\hline \multirow[t]{3}{*}{$\begin{array}{l}\text { Calif......... } \\
\text { Fla............ } \\
\text { Md............ } \\
\text { Mich.......... } \\
\text { Texas......... } \\
\text { Va........... } \\
\text { Wash....... }\end{array}$} & \multirow[t]{3}{*}{$\begin{array}{r}23 \\
6 \\
6 \\
17 \\
21 \\
9 \\
6\end{array}$} & \multirow[t]{3}{*}{$\begin{array}{r}30 \\
8 \\
7 \\
18 \\
22 \\
10 \\
7\end{array}$} & $\begin{array}{l}7 \\
2 \\
1 \\
1 \\
1 \\
1 \\
1\end{array}$ & \multirow[t]{3}{*}{ 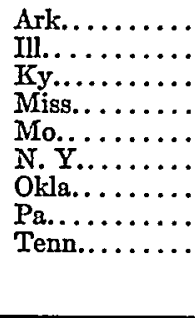 } & \multirow[t]{3}{*}{$\begin{array}{r}7 \\
26 \\
9 \\
7 \\
13 \\
45 \\
8 \\
33 \\
10\end{array}$} & \multirow[t]{3}{*}{$\begin{array}{r}6 \\
25 \\
8 \\
6 \\
11 \\
43 \\
6 \\
30 \\
9\end{array}$} & \multirow[t]{2}{*}{$\begin{array}{l}1 \\
1 \\
1 \\
1 \\
2 \\
2 \\
2 \\
3 \\
1\end{array}$} \\
\hline & & & 14 & & & & \\
\hline & & & & & & & 14 \\
\hline
\end{tabular}

The one state that has gained most from reapportionment is California. In I95I, half of the I4 seats went to California. During the years since IgII, when the House membership was frozen at 435 , California's net gain has been Ig congressmen. In other words, 50 House seats have been reapportioned since $19 \mathrm{rr}$, and California has received $4^{\circ}$ per cent of them.

\section{A. The Influence of Seniority}

The mere size of a state's delegation does not ensure success in the legislative process. There are many points in congressional procedure at which the seniority of a state's representatives may be even more decisive than the number of votes that might be mustered for or against a particular bill. Chairmen of standing committees wield great power over matters pending before their committees. These chairmen rise to the top by virtue of their membership in the majority party and unbroken seniority in Congress. Ranking minority members on a committee are also important persons; not only are they in line for the chairmanship in the event of a change in party control, but their long experience aids them in acquiring prestige and influence.

In addition to high position on a committee, or in the absence of such status, there are two other attributes of legislative ability: to have good standing with one's colleagues, and to possess a thorough working knowledge of law-making procedure. Other things being equal, these qualities should become more effective with increase in length of service.

The 7 states that gained congressional seats in $195 \mathrm{r}$ do not hold many high positions on the committees. Only Virginia has a chairman of a House standing committee, and at that it is a relatively unimportant body. ${ }^{25}$ Only Michigan, of the gaining states, has any ranking minority members; it has $4 .{ }^{20}$ On the other

\footnotetext{
${ }^{25}$ House Administration.

${ }^{20}$ Banking and Currency, Expenditures in the Executive Departments, Interior and Insular Affairs, and Public Works.
} 
hand, the 9 losing states rate high in both committee chairmanships and ranking minority members. Six of these states have committee chairmen; 4 have ranking minority members. ${ }^{27}$

It should be pointed out that the loss of $\mathrm{I}$ or 2 seats in the House is not going to damage greatly the power of such states as New York, Illinois, and Missouri, despite the disagreeableness and political inconvenience these losses cause. In part, the losing states may offset their losses with seniority power on House standing committees-a kind of power not possessed by the states that have gained representation.

In the Eighty-second Congress, first session, the average House member had served 8.5 years in Congress. The average length of service of the congressmen from 6 of the gaining states falls below the average: California, 7.7; Florida, 5.3; Maryland, 7.7; Michigan, 6.7; Virginia, 8.0; and Washington, 8.0. Only Texas with II. 5 is above the average. Looking at the losing states, 3 fall below the national average: Missouri, 7.I; Oklahoma, 5.8; and Pennsylvania, 7.8. Each of these losers suffers a loss of 2 or 3 congressmen in reapportionment. But 6 of the losing states have a record of congressional service that is higher than the national average: Arkansas, I0.9; Illinois, 9.8; Kentucky, 9.6; Mississippi, I3.x; New York, 9.2; and Tennessee, ir.6.

Assuming that average length of service is an important factor in measuring potential effectiveness of a congressional delegation, the losing states may further offset their losses by their above-average seniority levels in the House. The average seniority of the gaining states is significantly lower, and with each state being certain of at least one first-term congressman in the Eighty-third Congress, the disparity may then be even greater.

A state's congressional power cannot be assessed in the House of Representatives alone. Turning to the Senate, both gaining and losing states rate low in committee chairmanships and in ranking minority members. Of the gaining states, only Texas has a chairmanship; only Washington, a ranking minority member. ${ }^{28}$ And of the losing states, only Arkansas and Tennessee have committee chairmen; none of the losers has a ranking minority member. ${ }^{29}$ Furthermore, both gaining and losing states also have length-of-service records that are below the average of the Senate as a whole. In the Eighty-second Congress, first session, the average Senate member had served 6.5 years. Four of the 7 gaining states fell below the average: California, Florida, Maryland, and Michigan. Of the remaining states that gained by reapportionment, Texas and Virginia have 13.0 and 12.5 averages, re-

\footnotetext{
${ }^{27}$ States with committee chairmen: Illinois (Rules, and Expenditures in the Executive Departments); Kentucky (Banking and Currency); Mississippi (Veterans' Affairs); Missouri (Appropriations); New York (Judiciary, and Public Works); Tennessee (Post Office and Civil Service). States with ranking minority members: Illinois (Rules, Judiciary, and District of Columbia); Missouri (Armed Services); New York (Appropriations, and Ways and Means); Pennsylvania (Education and Labor).

${ }^{28}$ 'Texas (Foreign Affairs); Washington (Public Works).

${ }^{20}$ Arkansas (Expenditures in the Executive Departments); Tennessee (Post Office and Civil Service).
} 
spectively; Washington's is 7.o. Considering the 9 losing states, 6 fell well below the average length of service in the Senate. The 3 remaining loser states had aboveaverage seniority records: Arkansas, 8.0; Mississippi, 7.o; and Tennessee, with the most senior member of the Senate, Kenneth McKellar, rg.o.

Thus in the Senate the pattern of high position on committees and length of service in the upper house is unlike that found in the House of Representatives. Only Arkansas and Tennessee would appear to be in any way able to counterbalance the loss of seats in the lower house brought about by the 195I reapportionment.

- Statistics on the average length of service in both House and Senate suggest that, with the development of comparative data over longer periods of time, there may be significant correlations between the relative population increase or decrease of a state and the average seniority of its delegations in the House and Senate. The hypothesis for such a study may be stated thus: congressional seniority will tend to be lowest in states which increase most rapidly in population, but will be highest in states with the most stable populations. That this thesis exists for the House of Representatives seems more certain than for the Senate.

\section{B. Character of House Membership}

Some general observations may be made about the effect of the r95I reapportionment on the political complexion of the House of Representatives. Under the federal Automatic Reapportionment Act of 1929 , as amended in $194 \mathrm{I}^{30}$ states gaining representation in the House have two alternatives. They may either redistrict to provide for the extra seat or seats, or they may choose not to take any action. If they fail to act, the additional congressmen will be elected at large. The legislatures of the 7 states gaining congressmen are not, therefore, under great pressure to redistrict.

The governors and both houses of the state legislatures of 3 gaining states (Florida, Texas, and Virginia) are Democratic. These 3 states have been allotted a total of 4 new congressmen. Whether they reapportion or not, it should be safe to assume the four new representatives will be Democrats.

California is the only one of the 7 gaining states where the governor and both chambers of the legislature are Republican. California is also the only gainer to have reapportioned its congressional districts in 1951. A person unacquainted with California politics, or a partisan Democrat, might predict that all of the state's new congressmen will be Republicans. But a reasonable estimate might give Republican candidates a good opportunity in 2 of the 7 new districts, and a fair fighting chance in 2 or 3 of the others. The rearrangement of boundary lines in 2 existing districts might make it more possible for Republicans to defeat Democratic incumbents. Otherwise, the $195 \mathrm{I}$ redistricting process should produce no foreseeable changes in the party alignment of the congressional delegation. ${ }^{31}$

${ }^{30} 46$ STAT. 26 (r929), 55 STAT. 76I (194I), 2 U. S. C. \$2a and 2 b (Supp. 1950).

${ }^{81}$ Present party alignment of the California House delegation is ${ }_{3} 3$ Republicans and ro Democrats. 
California's weak political party structure, the close margin in the Assembly between Republicans (45) and Democrats (35), and the heavy predominance of Democratic registration throughout the state, all tended to offset some of the advantages that might have accrued to the Republican party by virtue of its control of the state government. ${ }^{32}$

In the 3 remaining states that gained representatives, two political parties must share in any state redistricting of congressional seats that takes place prior to the I952 elections. Both houses of the Maryland legislature have Democratic majorities, but its governor is a Republican. The situation is the reverse in Michigan, with the governor Democratic and the legislature Republican. The governor and senate in Washington are Republican while the lower house of the legislature is Democratic. Out of the kind of deadlocks likely to arise from situations such as these, the result will either be a compromise or inaction.

When a state gains congressmen yet fails to redistrict, the added representation must be elected at large. But when a state loses congressmen and fails to redistrict, one of the following alternatives applies. ${ }^{33}$ First, if the new number of congressmen is equal to the number of congressional districts, the candidates for Congress will have to run in the districts as they exist. ${ }^{34}$ Second, if the number of districts is less than the number of congressmen, one representative will be elected from each district and the remainder will be elected at large. Third, if the number of districts exceeds the total number of congressmen, the entire congressional delegation will have to run at large.

All of the states losing seats in $195 x$ fall into the third category. The pressure for redistricting in these states is quite strong. Experience such as Minnesota's in 1932 has shown that an unusually large number of incumbent congressmen are defeated when an entire House delegation of significant size is forced to run at large. Although New York, Missouri, and Tennessee are the only losing states that have reapportioned in $I 95 \mathrm{I}$, it is reasonable to assume that all of the losers will redistrict before the I952 elections.

Six of the 9 losing states have Democratic governors and legislatures. Of these, Kentucky might attempt to make its 2 Republican congressmen absorb its one district loss. The effect of Missouri's reapportionment might tend to operate against 2 of its 3 Republican incumbents. Oklahoma might try to reapportion both of its 2 Republicans out of office. And Tennessee might attempt to get rid of I of its 2 Republicans. Arkansas and Mississippi have no Republicans to offer in sacrifice; their loss of I seat each will have to come from the Democratic side. ${ }^{35}$

\footnotetext{
32 The following is the party alignment on the final votes in the California legislature on the I95I congressional reapportionment: Assembly Democrats for the bill 13, Republicans 36; Senate Democrats for the bill 8, Republicans 23 .

${ }^{33}$ Pub. L. No. 29I, 77th Cong., Ist Sess. (194I), 55 STAT. 76r, 2 U. S. C. \$2a(c). (Supp. I950).

34 For example, Connecticut has 5 congressional districts and 6 congressmen, the sixth at large. Had Connecticut lost a seat in $x_{95}$, it would have had 5 congressmen, and because it already had 5 congressional districts, it would not be necessary to reapportion.

${ }^{36}$ The following shows the present party alignments of the congressional delegations of the gaining and losing states. Gainers: California, I3 Republicans and ro Democrats; Florida, 6 D; Maryland, 3 R
} 
The governors and legislatures of New York and Pennsylvania are Republican. The readjustment of 43 seats in New York (down from 45) and 30 Pennsylvania seats (down from 33 ) might be worked to the advantage of the Republican party. ${ }^{36 \text {. }}$ Illinois has a Democratic governor and lower house, but a Republican senate. Generalization as to a party redistribution of its 25 seats (down from 26) is impossible.

Assuming that all the gaining and losing states do reapportion their congressional districts, the states with both Democratic governors and legislatures would control the redrawing of 75 district boundaries. Those states with both Republican governors and legislatures will recarve ro3 districts. And states with some split combination of party control will remake 57 districts.

In addition to the political character of the House membership, the urban-rural distribution must be noted. Prior to the I950 census, there were 21 urban and 27 rural states. Using the same standards for determination of an urban state, the population statistics of 1950 put 4 more states into the urban class. These 25 urban states have a total of 3 I2 House seats as against 123 seats for the 23 rural states. Using the Bureau of the Census' new standards for determining urbanization, 29 states are now so classified. On this new basis they would have 333 House seats as compared with ro2 seats for Ig rural states.

It is more important to look at the urban-rural character of individual congressional districts rather than states. Arthur $\mathrm{N}$. Holcombe has classified the districts as they presently exist into 130 urban, I25 mixed urban-rural, and I80 rural..$^{38}$ It is difficult to predict what the urban-rural distribution of congressional districts will be after the state legislatures have completed reapportioning on the basis of the I950 census. The trend in the direction of establishing more urban and mixed urban-rural districts is probably apparent, as it is only a reflection of population shifts from the farm to city areas. California's r95I reapportionment may serve as an example. ${ }^{37}$

Of the 3 congressional districts allocated to Los Angeles county, in addition to the 9 it now has, 2 should be classified as urban and the third as mixed urban-rural. One is located in the booming Lakewood section between downtown Los Angeles and Long Beach; a second combines Hollywood with part of the rapidly growing San Fernando Valley; a third, though it includes much sparsely settled area in the north portion of Los Angeles county, still deserves a mixed urban-rural classifica-

and $3 \mathrm{D}$; Michigan, $12 \mathrm{R}$ and $5 \mathrm{D}$; Texas, 2x D; Virginia, $9 \mathrm{D}$; Washington, $4 \mathrm{R}$ and $2 \mathrm{D}$. Losers: Arkansas, $7 \mathrm{D}$; Illinois, $18 \mathrm{R}$ and $8 \mathrm{D}$; Kentucky, $7 \mathrm{D}$ and $2 \mathrm{R}$; Mississippi, $7 \mathrm{D}$; Missouri, $9 \mathrm{D}$ and 3 R; New York, $23 \mathrm{D}$ and $22 \mathrm{R}$; Oklahoma, $6 \mathrm{D}$ and $2 \mathrm{R}$; Pennsylvania, $21 \mathrm{R}$ and $12 \mathrm{D}$; Tennessec, $8 \mathrm{D}$ and $2 \mathrm{R}$.

${ }^{35 a}$ The New York reapportionment has quite possibly been done at the expense of from two to six Democratic districts. See N. Y. Times, Dec. 9, I95I, $\$ 4$, p. 2 E.

${ }^{36}$ Arthur N. Holcombe, OUR More Perfect Union 130 (1950).

${ }^{37}$ California is $67 . x$ per cent urban by the old census definition and 80.7 by the ncw definition. Bureat of the Census, Population of California, April I, 1950, Advance Reports Series PC-8, No. 4 (October 14, 195I). 
tion because part of the San Fernando Valley is embraced by the new district boundary.

A fourth new urban district has been established for San Mateo county, immediately to the south of crowded San Francisco. A fifth new mixed district lies along the coast between the Los Angeles metropolitan area and the city of San Diego, and it might be termed suburban to both. The arrangements for the 2 new districts that went to the great Central Valley resulted from an overflow of San Francisco Bay-area population, and from the rapid growth of a whole string of valley cities, the most important of which are Sacramento and Fresno. ${ }^{38}$ Both of these latter districts deserve this mixed urban-rural classification. In sum, all 7 districts have been drawn to follow the population in its outward movement from the old urban centers to the new urban and suburban areas.

\section{The Influence of the California Delegation}

Considering California's large gain in congressional seats during the period from I900, the effects of the increasing size of the California House delegation deserve further attention. When California entered the Union in 1850 it was entitled to 2 congressmen. Even by 1900 it had only 7 representatives. But two big decades of growth raised the delegation from II to 20 members in 1933. The next largest addition, 7 new congressmen in 1953 , has brought the total to 30 .

It has been noted that California's average seniority in the Eighty-second Congress, first session, was 7.7 years, while the average for all of the states was 8.5. California's seniority rating in the House has never been high. It took 20 years, from the Thirty-first to the Forty-first Congress, before California's average rose as high as 4 years. In fact the average over the entire period of statehood is 5.I years. Prior to the turn of the century it was 3.2 years; since 1900 it has increased to 7.0 years.

California has had only 6 representatives who served 20 years or more in Congress. ${ }^{39}$ In the Eighty-second Congress, its most senior member in the House is serving his eighth term, 2 are serving their seventh, $x$ his sixth, and 4 are in their fifth iterm. Against this record of service is the fact that more than 45 other congressmen are today serving a ninth term or longer, and therefore rank above California's top man. As noted, California has no committee chairmen in the House; nor does it have any ranking minority members on committees. However, 3 Californians have survived long enough to be second on their party's side of their respective committees. ${ }^{40}$

Although California has increased the size of its House delegation more rapidly than any other state, why has its seniority level tended to be low? Fluidity of

${ }^{38}$ See map of California's $x 952$ congressional districts, in Hinderaker and Waters, $A$ Case Study in Reapportionment, infra.

${ }^{30}$ Julius Kahn (R'), 12 terms; Clarence Lea (D), 16; Charles Curry (R), Albert Carter (R), and Harry Englebright (R), ro; and Richard Welch (R), I2.

${ }^{\circ}$ Clair Engle (D), Interior and Insular Affairs; Chet Holifield (D), Expenditures in the Executive Departments; and Carl Hinshaw (R), Interstate and Foreign Commerce. 
population must be part of the answer. As one State Assemblyman remarked recently: "Here I have built up my name in my district for years and my father had built it up before me, and then all these new people come in and they never heard of us!" In part, weak parties are a factor, too. Without strong party organization, a premium is placed on individual congressmen to maintain their own bases of support. And this is made more difficult by the distance between Washington, D. C. and California which precludes frequent "fence mending."

Still another consideration is the fact that California's congressional district boundaries have been altered more than those of any other state as a result of repeated reapportionments. Except for the decade of the rgzo's, its districts have been reapportioned on the average of every Io years. On many of those occasions there have been rather drastic boundary shifts. Congressional district patterns in other states have not in general been subjected to such tampering. It is interesting that, with but one exception, California's seniority average in the House has gone down in the first Congress after each reapportionment. Then it has gradually built up until the next reapportionment, dropped, and then climbed back up again. In other words, the one-hundred year pattern of seniority takes on the appearance of an undulating line.

It is unlikely that there is a single explanation for the effect of reapportionment on these seniority cycles. Part of the answer may be attributed to the immediate aftermath of redistricting operations. Decrease would result, too, from the fact that new congressional seats had been added. Further, there have occasionally been critical political upheavals in elections that immediately followed congressional reapportionment. In 1912, for example, there was the Roosevelt-Taft-Wilson campaign, and in 1932 the New Deal was voted into power.

In general, the seniority rating of California's congressmen has increased since Igor. Seniority of the House delegation was one of the factors recognized and considered by the Assembly Interim Committee on Elections and Reapportionment when it made its recommendations for the congressional districts established in $195 \mathrm{r}$. Assuming a reasonable ability to maintain seniority, there are substantial and longrange advantages for the large delegation. First, it will have the voting power. Second, there are enough Californians to place one on every standing committee. Third, several may serve on a single committee at one time, and this tends to make it more certain that someone from the state will always have high rank on that body. New York is a good example with its 45 representatives strategically placed on the Ig standing committes.

California's delegation of 23 in the Eighty-second Congress is already large enough to operate in the same fashion as New York. Arizona and California are locked in mortal combat over Colorado River water in the Interior and Insular Affairs Committee. Arizona has one great advantage in Congressman John R. Murdock, chairman of the committee. His power, however, is partially held in check, because 
California has three representatives on Murdock's committee: Congressman Clair Engle, second ranking Democrat; Sam Yorty in the thirteenth Democratic position; and Norris Poulson, fifth ranking Republican. These men combine their talents without regard to party lines when issues of concern to California are at stake before the committee. As the delegation as a whole grows in the future, this multiple representation on committees will become one of the important elements of California's congressional power. ${ }^{41}$

There has been much speculation about the great increase in congressional power that has accrued to the "new West." When Democrats from II western states met in San Francisco in the fall of I949, major consideration was given to the problem of creating an audible voice for the West in national affairs. One speaker went so far as to suggest that the "Solid West" could be compared with the Solid South, and that the former was more important because it was based "on policy and program, not on blind party regularity."42

However, the congressional delegations of the western states do not constitute the regional-interest unit that some observers would like. The theme of the 1949 Democratic conference in San Francisco was "Land, Water, and Jobs." There is land and there are jobs aplenty in the West, but there is not enough water in the right places. Although the influx of population swelled the size of California's congressional representation, the increased demand for water by southern California has created political disharmony in Congress and has made relations between neighboring-state delegations in Congress more difficult. To say that water is a barrier to understanding between Arizona and California is an understatement. California has other problems of public relations, too. The Pacific Northwest reacts negatively and defensively to suggestions that southern California could be supplied with water from the great rivers of Oregon and Washington. Water is also a key to California's relationships with the Rocky Mountain states.

Another factor operating to make it more difficult for the California House delegation to secure support from other states, is a natural enmity against the state that is growing larger and larger each decade. The states which are losing representation, regardless of their geographical position in the United States, may resent California's taking seats away from them..$^{43}$ And they may be happy to join forces with California's neighboring states who may be genuinely afraid that California will use its new power contrary to their interests. ${ }^{44}$ At this time, then, California cannot be viewed as a working part of a self-interest bloc of western states in the Congress.

\footnotetext{
"For a discussion of the delegation see Farrelly and Hall, Californians in Congress, The Politics of California 228 (I95I).

"Neuberger, The "Solid West," I69 The Nation 346 (Oct. 8, I949).

"angressman Norris Poulson (R), Los Angeles, has cited this factor when speaking on the effects of the 1951 congressional reapportionment.

"Neuberger, The Case for Intertie, Frontier, Oct. I951, p. 13.
} 


\section{The Two Party System}

Parts of preceding sections have touched upon the implications of congressional reapportionment on political-party institutions. In the electoral college Republican states have lost votes to doubtful states during the last $4^{0}$ years. In the national nominating conventions held at Chicago in 1952 the Democrats have not reduced the representation of those states that suffered a loss in congressional seats, but the Republicans have immediately geared their convention to conform to the facts of the 195I reapportionment.

The rise of California to the status of a pivot state in presidential politics is a significant development growing out of the current reapportionment. The state is large in population and doubtful in election behavior. As to the essential characteristic of doubtfulness, a pivot state must have a political atmosphere in which Democrats and Republicans can compete on equal footing for its electoral votes. California meets this requirement better than any state. But in a national twoparty system, a local nonpartisan climate with weak parties operates against the state and prevents it from harvesting all the political fruits it might otherwise receive.

On the surface, the redrawing of congressional district lines within the states would seem to favor the Republican party. If redistricting is carried out in all $x 6$ states affected by reapportionment, Republican legislatures will recarve I03 districts, Democratic legislatures, 75, and split-party states, 57. The Democratic states, however, are the most firmly partisan in this group. They can hardly fail to employ partisan power so that it will work to their advantage in the redistricting process. The 3 largest states (New York, California, and Pennsylvania) will all have reapportioned before the 1952 elections, and each has a Republican governor and legislature. But there are some mitigating factors present in each case that work against any propensity to gerrymander in an indiscriminate fashion.

The trend of electoral votes and House seats to the doubtful type of state at the expense of traditionally Republican states is noteworthy. It means a shift in political power to states where each major party is forced to make a broad appeal for votes, not only to its own followers, but to independents and members of the opposite party. New York, California, and Pennsylvania may have elected their Republican governors and legislatures largely because of the influence of three men of broad appeal-Dewey, Warren, and Duff. Governor Earl Warren has won in California with what is perhaps the most successful nonpartisan appeal in the nation.

States in which a narrow Republican appeal still seems effective are losing electoral votes. The 5 leading corn-producing states (Indiana, Illinois, Iowa, Nebraska, and Minnesota), often the home of Republican standpattism and isolationism, have lost a total of to electoral votes from their highest combined strength. And one should perforce subtract 2 electoral votes from the wheat state, Kansas. None of these 6 states has been roo per cent Republican, but together they have consti- 
tuted the backbone of the G.O.P. since its birth. The corn belt used to be the key to Republican strategy, and "farmers of this section held a conscious balance of power in the party." ${ }^{35}$ With increasing urbanization and the flow of political power to seaboard states where voters are more internationally minded, a narrow sectional appeal may well be fatal.

The Democratic party has not suffered much decline in strength as a result of successive reapportionments. The Solid South retains about as much strength in the electoral college and in the House of Representatives as it has had throughout this century. There are some nascent indications, however, that the I940 to $195^{\circ}$ population trends may be making inroads into the solidarity of the southern states.

An interesting question emerges when one considers the transfer of northern industry and northern managers and workers to the South. Will migration affect the South's one-party system? It is reasonable to assume that most individuals take their party politics with them as they move from one section of the country to another. Many Republicans have emigrated to the Solid South. It is possible that the overwhelming Democratic strength will absorb this Republican potential. On the other hand, it is also possible that transplanted Republicans will flourish in a southern political climate. This latter speculation is no doubt attractive to those who still eye with hope the possible development of a two-party system in some sections of the South. Forthcoming data on migration from the Bureau of the Census may furnish some interesting facts which could shed light here.

While some Republican influence may be flowing from North to South, a potential Democratic influence is going the other way. In mid-November the Census Bureau announced that 7 southern states had lost a total of 250,000 Negroes during the decade ending in $195^{0 .}{ }^{46}$ Some had moved to Florida, but the vast majority had gone North. Others had moved to California.

The movement of the Negro does not mean a loss of Democratic votes in the South, because Negroes are still generally disenfranchised. But it does mean perhaps that he will influence the outcome of elections in doubtful states, or in states that lean toward the Republican party. One writer suggests the Negro already holds the batance of power in national politics by his large numbers in certain key northern states. ${ }^{47}$ Recent census figures may be employed to support this contention about the Negro vote.

The flow of political power to states in the doubtful category is a healthy trend for American democracy. It should put both major parties on their mettle. Population shifts that tend to break the South up into segments less-solidly Democratic are also healthful. It becomes more necessary, then, for the major parties to make broad appeals and campaign in almost all of the states. Campaigning may become more meaningful, and elections more productive of the kind of presidential and congressional leadership needed by the United States in the world of today.

40 W. E. Binkley, American Political Parties: Their Natural Historx 285 (1945).

${ }^{10}$ The Negro Moves, Time, Nov. 19 195I, p. 26, col. 3.

${ }^{47}$ H. L. Moon, Balance of Power: The Negro Vote to (1948). 


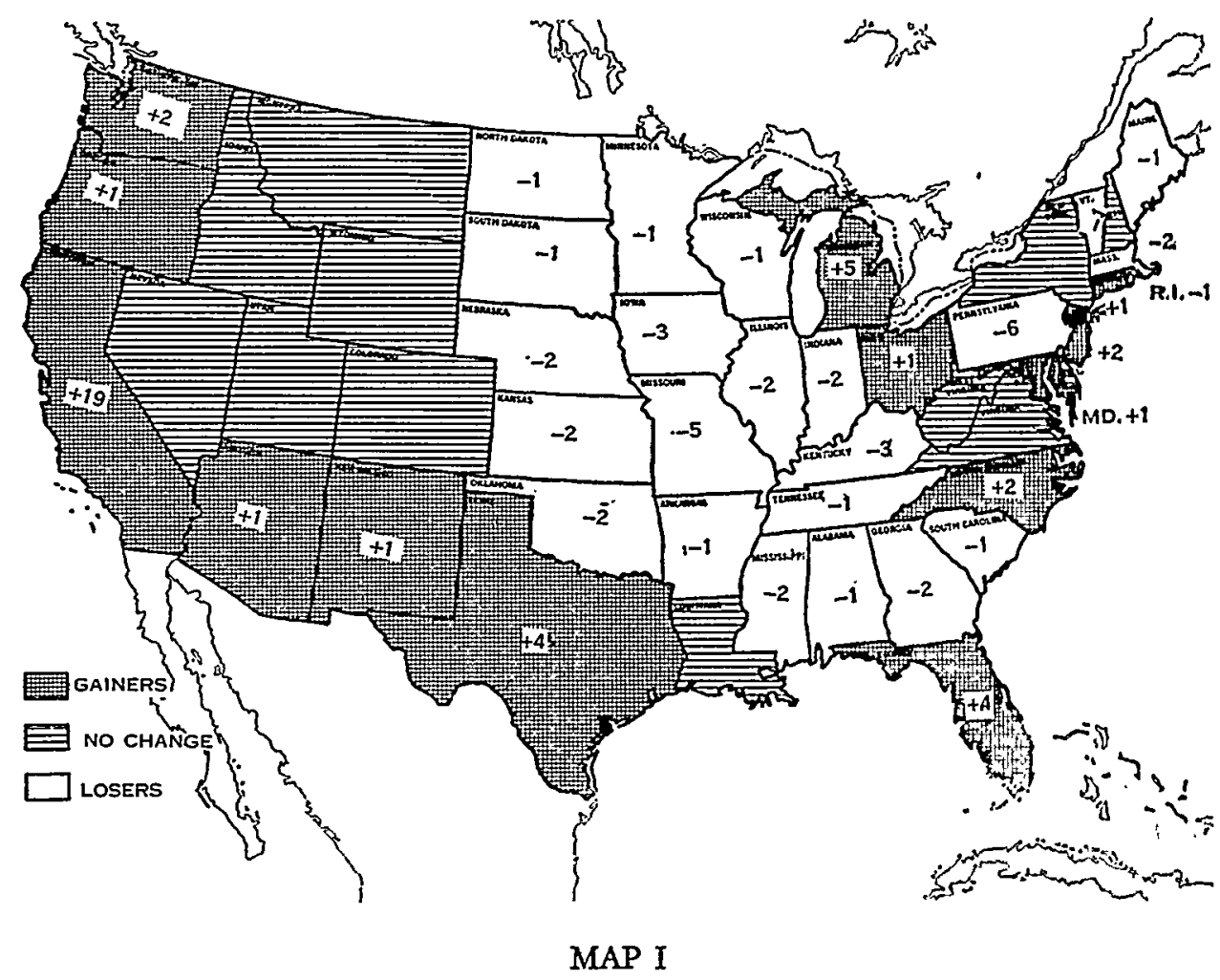

Changes in Electoral Vote and House Representation, 1912-1952 


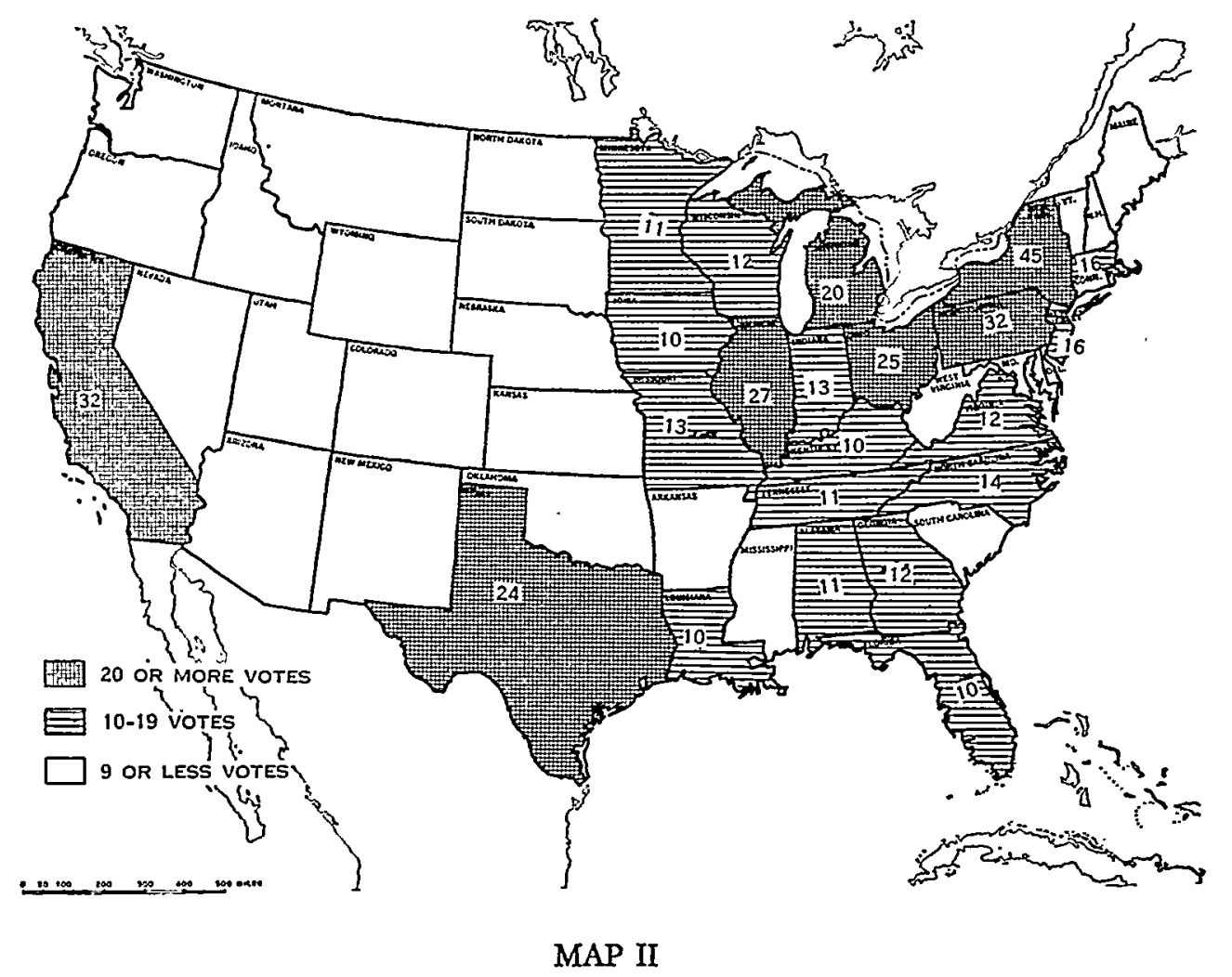

States With io oR More Electoral Votes, 1952-1960 